\title{
Identity in Literacy Artefact of Elementary School Student
}

\author{
Sri Rahayu, Bambang Yulianto, Suhartono \\ Universitas Negeri Surabaya \\ Surabaya, Indonesia \\ srirahayu16070855407@mhs.unesa.ac.id
}

\begin{abstract}
Identity is the most important thing of language teaching, because identity has the most role makers in literacy. As the important thing in the learning of literacy, this identity makes a different character from any literacy practice of students' products. Student literacy product can be collected based on the variety or type of literacy performed. The collection of these literary works is commonly called artifacts. These literacy artifacts include student essays, poems, short stories, mind maps, personal letters, etc. This literacy artifact can show the identity of the students according to their own experience, their hobbies or their interest, and social status. This chapter uses descriptive qualitative approach that will be used to view the description of student's identity in his/ her learning experiences and interest. This identity is elaborated descriptively and uses theoretical data to support the invention. This research shows that identity of student experience and interest can show the student character, ability in learning and identity of their literacy proficiency. From this identity, the teachers allow to take creative and effective strategies to accommodate any different students of learning needed in literacy practice.
\end{abstract}

Keywords - Literacy, Artefact Literacy; Experienced Identity; Interested Identity

\section{INTRODUCTION}

Literacy activities undergo the development in programs and their implementation in schools of various countries [1]. Today literacy is known not only read and write it, but has developed in various field of study. According to Wiedarti, Laksono, et al., literacy also includes complex thinking skills, using knowledge resources in print, visual, digital, and auditory forms all of which are called information literacy. Literacy of this information includes [2] early literacy, basic literacy, library literacy, media literacy, technological literacy, and visual literacy.

In practice, the person said to be literate will have sensitivity to the surrounding environment. The person will have a different perspective in facing the problem both for himself and for the welfare of the surrounding. This means that the sharpness of thought sharpened with literacy activities will have a deeper meaning in the activities of one's life. When the person sees a natural phenomenon and the person has a meaning based on the development of visual literacy in nature, for example, then he will show behavior that shows the benefits to life. This can make a person of a different character than those who have not practiced the whole literacy activities in daily life (Sukartiningsih [2018] and Hendratno [2018]).

In terms of identity with literacy, some theories reveal that identity in literacy has its own meaning in shaping the literacy practices. Pahl \& Rowsell reveals [3] that most literary works in the form of writing, drawing, audio, sketch, mind map and so on are influenced by the underlying identity of the work. This identity forms the work in such a way that it has its own character of each creator. This identity can also be formed from the background of experience, joy, social and prior knowledge of the creator of the work. The identity that affects this work can reveal the background state, whether it is the social background, the family, the environment in which it lives, the experience, the concentration, and so on.

Based on this opinion, North explains [4] that the child's identity and experience background will shape the wealth of his works. Students will write, compose poems, create pantun, paraphrase poetry, write stories and answer questions based on their previous experience. Similarly, when children from art enthusiasts' backgrounds, they will create a mind map of the colors, they decorate with the crayons or colored pencils they have. This linkage is important in literacy practices that will shape their experience as well as' colorize 'the students' identity better for the learning activities they experience.

Student identity is also the heart of language teaching [3]. To train students' language skills, a teacher can explore students' experiences and provoke students' desires from their backgrounds. The addition of foreign language learning is also based on student identity. Starting from the things close to the student environment, then describe it in writing or in the story of the student story. Students can retell it easily even if using a foreign language, ranging from things close to the world of students and the preferred ones. The results of this activity can be developed into a collection of literacy works that can be used as a reference assessment of student achievement learning outcomes.

\section{THEORETICAL REVIEW}

\section{A. The Development of Meaning of Literacy}

Today, literacy in various research and educational progress continue to experience both in terms of both meaning and practice. In many cases, literature is now associated with 
other words, such as reading literacy, media literacy, social literacy, scientific literacy, etc., which is related to the mention of literacy meaning in the field of words that follow [5].

The various views that underlie the development of literacy meanings lead to one estuary of ability that is the ability to understand, analyze, then to be able to take action on the results of his understanding. In other terms, this is referred to as problem-solving, i.e. the ability to overcome problems. Eisner (in Abidin, 2017: 4) has a view that is consistent with this. Eisner argues [6] that literacy is a way of discovering and taking on the meaning of the various representations that occur around us.

This is in line with Luke's expression, [6] which reveals that literacy skills are not only able to read and write, but also able to view thorough, thematic, interdisciplinary, and multimodal knowledge. Thus, a literate person (who has literacy ability) can solve problems precisely by understanding conditions and literate on the events around him and can make a problem as a means of learning and progress of knowledge owned. A person who is literate can withstand various limitations because in essence has the ability to solve problems for yourself and for others.

In subsequent developments, literacy becomes a multi literation term. Multiliteration is translated as the development of the basic literary concept that leads to the formation of literacy in various fields of study. According to Abidin et al [6], multiliteration has a sense of the various ways used to declare and understand information ideas, using conventional text forms as well as innovative texts, symbols, and multimedia. Thus, the ability to be mastered by students will vary based on the expertise in understanding the various forms of text, media, and symbol systems. It is intended to maximize their ability to understand and follow technological developments, maximize their learning potential, and participate actively in the global community.

This concept is in line with Eisner's thought $\backslash$ and in accordance with Pahl \& Rawsell's opinion which explains that multiliteration is the ability to read, write poetry, divide, paint, dance, write novel, or contact with media requires literacy. Thus, it can be concluded that Eisner argued about literacy which is not only looked at the meaning of written symbols but also from various symbols that contain meanings existed around. This is also the same with the expression Sukartiningsih that the literacy is the ability to interpret something that is around.

\section{B. New Directions Literacy Learning}

Literacy has a very wide effect in the formation of private and cultural society (Mujib, 2016). From this statement, it is clear that literacy is important for cultural change and development. With the existence of literacy, people's understanding is increasing to a phenomenon. The findings in various fields also result from the practice of literacy in the field. Science, for example, there has been many inventions and technologies that are very useful for human life. Without the awareness and practice of sustainable science literature, these discoveries in science and technology will not happen. The new direction of literacy learning as described earlier becomes a new opportunity for developing learning techniques. The technique used will not be applied maximally if it does not know the essence of the problems that became the foothold in the development of literacy learning. From that point, it is determined first in a clear direction in literacy learning in schools and elsewhere that support this literacy movement.

Morocco in Abidin [6] puts forward the view of the learning objectives and competencies that must be mastered in the 21 st century is to develop four pillars of competence: high concepts, communication, and collaboration, critical thinking, creative. Related to this matter, literacy has a function as a learning facilitator for these four competencies.

\section{Identity and Literacy Artifacts}

Kate Pahl and Rawsell in the book Literacy and Education, reveals [3] that children's work in literacy activities needs to be rewarded by bringing them to spaces that match the characters or identities that appear in their work. Their works are known for their student artifacts. Artifacts do not mean historic relics of the past. This literacy artifact has a historical significance in the history of the work maker. The history in question is the identity of students who are recorded in the work they have such as posters, student essays, poetry, and so forth.

Artifacts in the literature have an important role to know the trace of development of student literacy learning. In the artifacts student text can be seen from time to time during the certain period, develop or not. From the artifacts, it can also be identified consistency of the student identity.

The artifacts of students who have unique identities, strong in the expression of experience, likes and social status of their families will have their own independence for teacher evaluation in learning. It can happen in the writing (text) of students they write in the diary or on the reflection sheet of their daily activities, they give a special symbol or sign like emoji that can express their feelings.

Associated with the artifacts, identity in literacy artifacts can show the background of the artifact maker. The identity in question at least includes the identity of the experience and favorite identity. The identity of experience, according to Papalia, Sally and Fieldman explain [7] that the development of the identity of this experience is of course influenced by many factors. The most influencing factor is the environment, both the environment from within and the environment from outside. That is a world outside of self that begins with the womb, and learning gained from experience. This experience will be an identity or character of a person who will affect the pattern of his life.

Identity can be formed through group games, the environment close to the students, or the various backgrounds [8] that the student has. When sharing knowledge and 
experience at school, the students will share their respective identities. These identities can complement and support each student at the same time. School will become the norm for the development of this identity.

Along with the development of information technology, currently also can be found digital identity as proposed by Pahl \& Rawsell. This digital identity can be encountered in student artifacts such as digital images, mize, posters downloaded from the internet, robot images that children play, soccer team logos they upload, and so on. This digital identity child gets from the experience of using the internet. Children learn about cyberspace and pour it into their work.

Hurlock describes [9] that at the age of the children, they will have the tendency to love the game. Popular games for children according to Hurlock are free and spontaneous play, drama, daydreaming, constructive play, music, collectibles, sports, entertainment such as television, reading. Children's favorite reading themes are generally imaginary stories, stories about animals, and adventures.

\section{METHOD}

\section{A. Approach and Type of Research}

The approach used in this research is qualitative. In research with qualitative method, the data is described as is and descriptive research result done descriptively. This qualitative approach is used to identify the results of research from field data in depth, i.e. from student artifacts collected during the learning takes place. Both the learning outcomes at school and the results of cooperation should be talked with the parents at home.

The type of research used is descriptive. Namely the translation of the research process and the object of research as it is without any special treatment from researchers. In this research will be expressed the identity and identity on the artifacts of student literacy descriptively. The role of the researcher in this case only observes the actual situation in the field and then write it on the research focus. So, this study describes the process of expression of the experienced identity and identity that exist in the artifacts of student literacy.

\section{B. Data and Data Sources}

1. The data used in this study are excerpts from literacy artifacts of primary school students in fifth grade.

2. The sources of data studied are the work of students in literacy activities that include: student essay in the form of papers, poems, pantun, notebooks, posters, personal letters. This data source is taken from SDN Made 1 Surabaya which has implemented School Literacy Program with Reading Writing Time activity program in school.

\section{Data Analysis Technique}

The obtained data is analyzed descriptively using an observation sheet designed in accordance with the research focus. In addition, a simple calculation is used to get the result of identity appearance on student artifacts with simple tabulation. These instruments include: (1) description notes, i.e. description of the identity of experience and liking on students' literacy artifacts; (2) a closed questionnaire for students; (3) interview guidelines.

This descriptive research technique uses the procedure [10] as follows: (1) reducing the data, done by reading the data of observation result of the expression of identity in student literacy artifacts; (2) interpreting the data, done descriptively from data that has been analyzed in the previous stage; (3) explanation of the data, i.e. the data obtained is explored based on the instrument description note sheet, questionnaire, and interview about identity on student literacy artifacts then tabulated; (4) presents data descriptively; (5) summarizes the data (includes the discussion of research result).

\section{RESULTS AND DISCUSSION}

After analyzing the data with tabulation then obtained the following results.

\section{CHART 1. THE RESULT OF REPRESENTATION ANALYSIS OF THE IDENTITY OF EXPERIENCE AND FONDNESS ON STUDENT LITERACY} ARTIFACTS.

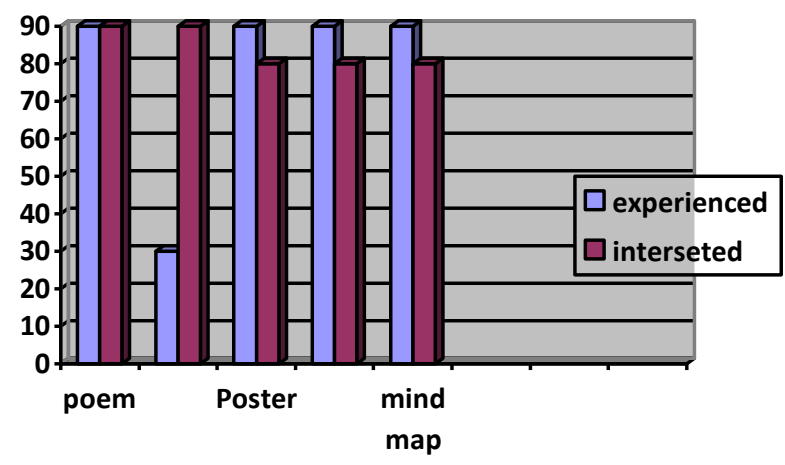

Chart 1 above shows that on student literacy artifacts, the identity of the learning experience appears in most of the students' work. This learning experience is seen in the work of students with the typical style of each student. In one of the works such as poetry, the identity of students' experience emerged $90 \%$ of the work of all children.

In the poster work and concept maps also almost all show the experience of $80 \%$ of students. This experience shows students' activities in the cognitive exercise of ideas or ideas. In the work of making pantun, the prominent thing is shown by the favorite identity. The average student chooses a simple word in making pantun and every day they meet. Learning experience is only shown by $30 \%$ of students in making pantun.

The identity of the average experience is their pleasant experience. Unpleasant experiences are expressed in their free essay on narrative papers and personal letters. 


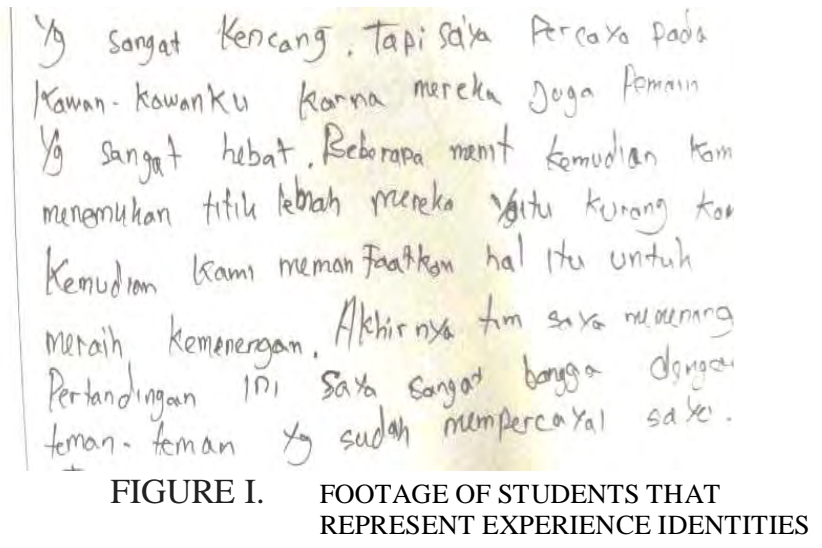

The picture above is a snapshot of a narrative writing work on a preferred activity. In the picture above can be seen that the student wrote his experience playing fun futsal. On the written biodata, it can be seen that the preferred game of him is futsal. This activity is done by a team. Learning experience is shown in the choice of words used "A few minutes later we found their group's weak point, which is less compact". This chosen vocabulary can be gained by the experience of children looking at football matches. Written terms indicate this.

Pleasant experience is also shown by students' writing. This is shown in Figure 2 below.

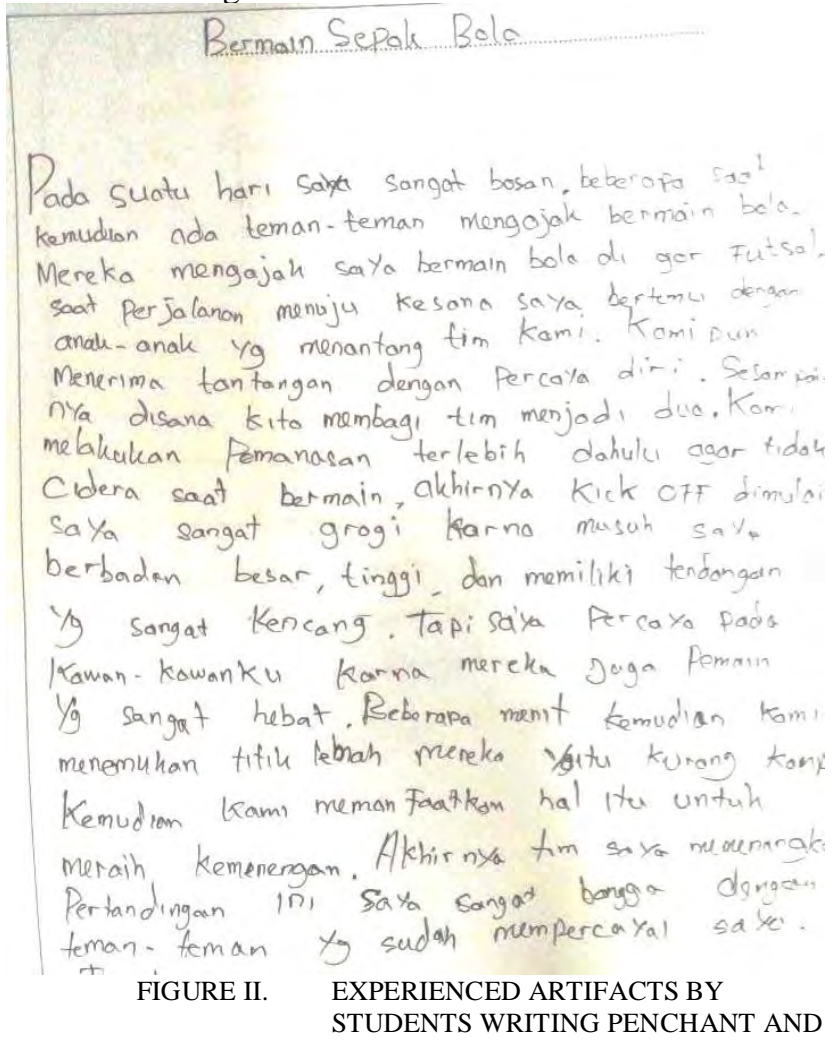

Figure 2 shows an artifact that tells a pleasant and unpleasant experience at once. This experience is written by a girl who has a playful likeness to boys. In the last sentence in the text it says, "I also love to play football so I always bought football clothes by my father from second grade to fifth grade. Because of that, I barely have a skirt. Ha ha ha".

The students' experience is in accordance with Hurlock's and Djamarah theories that at the elementary school age, the things children love about are adventure and group play, such as soccer groups.

There are three works that show $80 \%$ of students represent a favorite identity. The works are posters, personal letters, and concept maps. Some tend to color a concept map of various colors, emblazoned with a picture of a reminder and a special mark. Some students also give special symbols on the literacy work on student's favorite soccer team, Persebaya Surabaya.

\section{CONCLUSION}

The conclusions and suggestions that can be drawn from the discussion are:

1. The identity represented by the literacy work of the student indicates a learning experience, pleasant experience, disagreeable experience, and favorite identity;

2. Literacy artifacts of the students have a variety of identities that can be used as a reference to determine the learning model;

3. Mapping representation of experience identity shows $90 \%$ of students have experience that has been poured on their work;

4. To produce good literacy artifacts, the teachers should facilitate the students needs according to the identity shown;

5. The teacher rewards the work the student has produced.

\section{References}

[1] K. Sumardi, "Pendidikan Keaksaraan Dasar Melalui Metode Kombinasi Bagi Wanita Miskin dan Tuna Aksara di Pedesaan Indonesia," Jurnal Educationist, vol. 3, pp. 60-68, 2009.

[2] T. Septiyantono, "Literasi Informasi," 2014.

[3] K. Pahl and J. Rowsell, Literacy and education: SAGE Publications Ltd, 2012.

[4] S. North, "Disciplinary variation in the use of theme in undergraduate essays," Applied Linguistics, vol. 26, pp. 431-452, 2005.

[5] P. V. Paul, "New literacies, multiple literacies, unlimited literacies: What now, what next, where to? A response to Blue Listerine, parochialism and ASL literacy," Journal of Deaf Studies and Deaf Education, vol. 11, pp. 382-387, 2006.

[6] Y. Abidin, T. Mulyati, and H. Yunansah, "Pembelajaran Literasi Strategi Meningkatkan Kemampuan Literasi Matematika, Sains, Membaca, dan Menulis," Jakarta: Bumi Aksara, 2017.

[7] D. E. Papalia, S. W. Olds, and R. D. Feldman, "Human development (psikologi perkembangan) edisi kesembilan," Jakarta: kencana, 2008.

[8] M. de Haan, R. Keizer, and E. Elbers, "Ethnicity and student identity in schools: an analysis of official and unofficial talk in multiethnic classrooms," European journal of psychology of education, vol. 25, pp. 176-191, 2010.

[9] E. B. Hurlock, "Perkembangan Anak Jilid 1 (Alih Bahasa: Meitasari Tjandrasa dan Muslichach Zarkasih)," Jakarta: Erlangga, 1978.

[10] I. Gunawan, "Metode penelitian kualitatif," Jakarta: Bumi Aksara, 2013. 